\title{
Seed and Oil Productivity upon Foliar Spray of Soybean (glycine max 1.) with Humic and Ascorbic Acids with or without Seed Irradiation
}

\author{
A.M. Helmy \\ Soil Science Deptartment, Faculty of Agriculture, Zagazig \\ University, Zagazig, Egypt.
}

\begin{abstract}
7 HE STUDY evaluates the beneficial effects of soybean foliar 1 spray with humic acid (HA) and ascorbic acid (AA) antioxidants at $2000 \mathrm{mg} \mathrm{L}^{-1} \mathrm{HA}$ and 300 and $600 \mathrm{mg} \mathrm{L}^{-1} \mathrm{AA}$; and seed irradiation of 15 and $30 \mathrm{~Gy}$ gamma rays. The split-plot experiment was conducted on a sandy soil in Ismailia Governorate, Egypt, during 2010 summer season. Main plots were for foliar spray treatments of: none, HA, AA1, AA2," HA+AA1"," HA+AA2"; AA1 and $\mathrm{AA} 2$, i.e. 300 and $600 \mathrm{mg} \mathrm{L}^{-1}$. Sub-plots were for irradiation of, none, 15Gy and 30Gy. 100-seed weight, straw and pod yields as well as protein, N, P, K and oil contents; protein and oil yields and N, P and $\mathrm{K}$ uptake increased by $15 \mathrm{~Gy}$ than by $30 \mathrm{~Gy}$. Main effect of spray shows a general descending order of "HA+AA2" > "HA+AA1" > HA > AA2 > AA1. Highest straw yield $\left(5.82 \mathrm{Mg} \mathrm{ha}^{-1}\right)$ was by $\mathrm{HA}+\mathrm{AA} 1+15 \mathrm{~Gy}$. Highest seed yield $\left(2.99 \mathrm{Mg} \mathrm{ha}^{-1}\right)$ was by $\mathrm{HA}+\mathrm{AA} 2+30 \mathrm{~Gy}$. Highest uptake of P $\left(23.2 \mathrm{~kg} \mathrm{ha}^{-1}\right)$ and $\mathrm{K}(206$ $\left.\mathrm{kg} \mathrm{ha}^{-1}\right)$, respectively at straw were achieved owing to the addition of $\mathrm{HA}+\mathrm{AA} 1+15 \mathrm{~Gy}$ gamma ray while treatment of $\mathrm{HA}+\mathrm{AA} 2$ with $15 \mathrm{~Gy}$ gamma ray gave highest $\mathrm{N}$-uptake (163 $\left.\mathrm{kg} \mathrm{ha}^{-1}\right)$. Highest $\mathrm{N}, \mathrm{P}$ and $\mathrm{K}$ uptake in seeds $(149,19.1$ and $49.0 \mathrm{~kg}$ $\mathrm{ha}^{-1}$, respectively) were by (HA+AA2+15Gy gamma ray dose). The treatment of HA+AA2 with $15 \mathrm{~Gy}$ gamma ray was superior to the other treatments.
\end{abstract}

Keywords: Sandy soil, Soybean, Humic and ascorbic acid, Seed irradiation with gamma ray

Soybean (Glycine max L.) is an important oil and protein crop; it contains about $30 \%$ of cholesterol free oil and about $40 \%$ of protein beside vitamins. In Egypt, soybean oil has been used as edible oil during the past 40 years; and its extraction ratio of oil is about $20.5 \%$ (El-Agroudy et al., 2011). Recently, attention has been directed to increase productivity of soybean to be used as protein source (particularly for animal feeds and oil for human food). Total production of soybeans in Egypt reached 23000 tonnes in the year 2013, produced from an area of 8000 ha $(\mathrm{FAO}, 2013)$. Therefore, it is of great importance to increase its production.

Gamma irradiation can be useful for alteration of physiological characters (Kiong et al., 2008). The biological effect of gamma rays leads to useful changes in seeds (Kovacs and Keresztes, 2002). Pre-sowing seed irradiation is an 
effective method increases seed production and improves seed quality since it ionizes molecules and causes free radicals to attack DNA breaking one or two of their molecules (Jyoti et al., 2009). Gamma irradiation in a low dose (10, 20 and 30Gy), increased seed yield of sesame plants (Farag and El-Khawaga, 2013).

The use of humic acid as a fertilizer has increased with increasing agricultural production and could be applied directly to the soil or as foliar spray to plants. Bioorganic fertilizers are used to reduce environmental pollution along with reducing the production cost and to improve crop quality (Asik et al., 2009). The action of humic acid on plant growth can be divided into direct and indirect effects. It affects plant membranes increasing the transport of plant nutrients, enhancing protein synthesis, photosynthesis, microbial activity and solublization of micronutrients, reducing the active levels of toxic elements (Saruhan et al., 2011). In a study on effects of bio and mineral fertilizers and humic substances on growth and yield of cowpea Magdi et al. (2011) reported that, chemical fertilizer with humic substances improve growth and yield of cowpea. Mahmoud (2006) found that treatment of humic acid increased straw and seed yields as well as oil and protein content in peanut.

Ascorbic acid in plants functions as an antioxidant and an enzyme cofactor. It participates in a variety of processes, including photosynthesis, cell wall growth and cell expansion, resistance to environmental stresses and synthesis of ethylene, gibberellins, anthocyanine and hydroxyl proline (Galal et al., 2000 and Smirnof \& Wheeler 2000).

The objective of the present study was to examine the impact of foliar applications with ascorbic acid as an antioxidant and humic acid on seed yield, seed quality and uptake of nutrients in soybean cultivated in a newly reclaimed sand soil after seed treatment with two doses of gamma irradiation, i.e. 15 and $20 \mathrm{~Gy}$ or without irradiation.

\section{Materials and Methods}

A field experiment was carried out during the successive summer season of 2010 and at private farm in Ismailia Governorate, Egypt, in order to investigate the effect of foliar applications with an antioxidant, i.e. ascorbic acid and humic acid on yield, seed quality and nutrients uptake of soybean (Glycine max L. cv Giza 35). Soil samples were taken at the depth of $0-30 \mathrm{~cm}$ before planting for physical and chemical analysis as shown in Table 1 ( Page et al., 1982).

Egypt. J. Soil Sci. 55, No. 3 (2015) 
TABLE 1. Physical and chemical properties of the investigated soil .

\begin{tabular}{|c|c|c|c|c|c|c|}
\hline \multicolumn{3}{|c|}{ Property } & Value & \multicolumn{2}{|c|}{ Property } & Value \\
\hline \multicolumn{3}{|c|}{ Particle size distribution } & & \multicolumn{2}{|c|}{ Soluble ions $\left(\right.$ mmolc $\left.^{-1}\right)$} & \\
\hline Clay & \multicolumn{2}{|c|}{ ize distribution } & 3.89 & \multicolumn{2}{|c|}{$\mathrm{EC}\left(\mathrm{dSm}^{-1}\right)$ in soil paste } & 0.66 \\
\hline Silt & \multicolumn{2}{|l|}{$\%$} & 2.71 & \multicolumn{2}{|c|}{$\mathrm{Na}^{+}$} & 0.65 \\
\hline Fine sand & \multicolumn{2}{|l|}{$\%$} & 25.3 & \multicolumn{2}{|c|}{$\mathrm{K}^{+}$} & 1.59 \\
\hline Coarse sand & \multicolumn{2}{|l|}{$\%$} & 68.1 & \multicolumn{2}{|c|}{$\mathrm{Ca}^{++}$} & 2.55 \\
\hline \multicolumn{3}{|c|}{ Textural class } & Sand & \multicolumn{2}{|c|}{$\mathrm{Mg}^{++}$} & 1.31 \\
\hline \multicolumn{3}{|c|}{$\mathrm{pH}$ [Soil suspension $1: 2.5$ ] } & 7.79 & \multicolumn{2}{|c|}{$\mathrm{Cl}^{-}$} & 1.32 \\
\hline \multicolumn{3}{|c|}{ Organic matter $\left(\mathrm{g} \mathrm{kg}^{-1}\right)$} & 7.38 & \multicolumn{2}{|c|}{$\mathrm{HCO}_{3}{ }^{-}$} & 3.19 \\
\hline \multicolumn{3}{|l|}{$\mathrm{CaCO}_{3}$} & 4.56 & \multicolumn{2}{|c|}{$\mathrm{SO}_{4}=$} & 1.59 \\
\hline \multicolumn{7}{|c|}{ Available macro and micronutrients ( $\mathrm{mg} \mathrm{kg}^{-1}$ soil) } \\
\hline $\mathbf{N}$ & $\mathbf{P}$ & $\overline{\mathbf{K}}$ & $\mathbf{F e}$ & Mn & $\mathbf{Z n}$ & \\
\hline 27.3 & 3.18 & 83.5 & 2.98 & 0.88 & 0.33 & \\
\hline \multicolumn{7}{|c|}{ Critical levels of nutrients in soil after Page et al., (1982) } \\
\hline Limits & $\mathbf{N}$ & $\mathbf{P}$ & $\mathbf{K}$ & $\mathrm{Fe}$ & Mn & $\mathbf{Z n}$ \\
\hline Low & $<40.0$ & $<5.0$ & $<85.0$ & $<4.0$ & $<2.0$ & $<1.0$ \\
\hline Medium & $40-80$ & $5-10$ & $85-170$ & $4-6$ & $2-5$ & $1-2$ \\
\hline High & $>80.0$ & $>10.0$ & $>170$ & $>6.0$ & $>5.0$ & $>2.0$ \\
\hline
\end{tabular}

"Extractants of available nutrients: $\mathrm{NH}_{4} \mathrm{HCO}_{3}-\mathrm{DTPA}(\mathrm{P}, \mathrm{K}, \mathrm{Fe}, \mathrm{Mn}$ and $\mathrm{Zn}), \mathrm{KCl}(\mathrm{N})$.

The experiment was in a randomized complete block design, split-plot involving two factors:-

Factor 1 " main plots": Foliar spray (F) with the following 6 treatments:-

1-No spray; 2- Humic acid spray (HA); 3- Ascorbic acid spray1 (AA1); 4Ascorbic acid spray2 (AA2); 5- " HA+AA1"; 6-" HA+AA2". Concentrations of spray solutions were: $2000 \mathrm{mg} \mathrm{K}$-humate $\mathrm{L}^{-1}$ for HA, $300 \mathrm{mg} \mathrm{L}^{-1}$ for AA1 and $600 \mathrm{mg} \mathrm{L}^{-1}$ for AA2.

Factor 2 " sup plots": Seed irradiation with gamma ray (Gy) with the following treatments:-

A-No irradiation, B- irradiation dose of 15 Grays (15Gy) and C- irradiation with 30 Grays (30Gy). Irradiation source was cobalt 60 gamma chamber 4000-A-India, Egyptian Atomic Energy Establishment, (EAEE), Inshas, Egypt.

Spraying with HA was done in two occasions: at 30 and 45 days after seeding, (DAS). Humic acid material (85\%) was used as a commercial product supplied by Biotech for Bio-acids Fertilizer Company, Egypt while ascorbic acid was in a form of commercial product. Seeds of soybean (Glycine max L. c.v. Giza 35) was sown after soil preparation. Seeding was carried on June $15^{\text {th }}, 2010$. Spraying with AA was done in three occasions 10, 20 and 30 DAS. Spraying with combinations of HA+AA was done separately for each material not in one mixed solution.

The plot area was $5 \times 4 \mathrm{~m}^{2}$. Each plot consisted of 12 rows $40 \mathrm{~cm}$ apart with two plant / hill every $20 \mathrm{~cm}$ and thinned to a single plant per hill 21 days after seeding. 
Seeds were treated with an effective strain of Bradyrhizobium japonicium just before seeding. All plots received N, P and K. Nitrogen was added at $120 \mathrm{~kg} \mathrm{~N}^{-1}{ }^{-1}$ as ammonium sulphate, AS (206 $\left.\mathrm{g} \mathrm{N} \mathrm{kg}^{-1}\right)$ in three equal splits: immediately after planting as a starter, 40 and 60 DAS. Phosphorus was added at $31 \mathrm{~kg} \mathrm{P} \mathrm{ha}^{-1}$ as calcium superphosphate $\left(67.6 \mathrm{~g} \mathrm{P} \mathrm{kg}^{-1}\right)$ during seedbed preparation; and potassium was added at $100 \mathrm{~kg} \mathrm{~K} \mathrm{ha}^{-1}$ as potassium sulphate $\left(400 \mathrm{~g} \mathrm{~K} \mathrm{~kg}^{-1}\right)$ in two equal splits 30 and 45 DAS.

At maturity, ten plants were taken randomly from each plot and used for yield assessment. The 100-seed weight was measured. In addition, plants of two rows in each plot were harvested; air dried, then yields of Pods, straw and seeds were determined and expressed in megagrams per hectare $\left(\mathrm{Mg} \mathrm{ha}^{-1}\right) ;\left(\mathrm{Mg}=10^{6} \mathrm{~g}\right)$. Also, shelling percentage $\%$ was determined $=$ seed yield $/$ pod yield X 100. Seeds were analyzed for contents of oil, N, P and K. Protein content was determined by multiplying seed N\% by $5.71(\mathrm{FAO}, 2003)$. Protein yield $\left(\mathrm{kg} \mathrm{ha}^{-1}\right)=$ protein content $(\mathrm{g}$ $\left.\mathrm{kg}^{-1}\right) \mathrm{X}$ grain yield, $\mathrm{Mg} \mathrm{ha}{ }^{-1}$. Oil yield $\left(\mathrm{kg} \mathrm{ha}^{-1}\right)=$ oil content $\left(\mathrm{g} \mathrm{kg}^{-1}\right) \mathrm{X}$ grain yield, $\mathrm{Mg}$ $\mathrm{ha}^{-1}$.

Methods of analysis

Plant samples were digested with a mixture of concentrated sulfuric and perchloric acids for nutrient determinations using the methods described by Chapman \& Pratt (1961). Soil analyses were done by methods described by Black et al. (1965) and Lindsay \& Norvell, (1978). Nutrients in digests were measured using Inductively Coupled Plasma (ICP) Spectrometer model 400 while, $\mathrm{N}$ was determined by kjeldahl. Oil content was determined using Soxhlet method (AOAC, 1990).

\section{Results and Discussion}

\section{Yield and yield components}

100-seed weight

Data relating the 100-seed weight and yields of soybean are presented in Table 2 . The growth parameter of 100 -seed weight significantly increased due to foliar spraying with $\mathrm{HA}$ and/or AA; and also duo to seed gamma irradiation. As for the foliar spray, the main effect shows that spray with HA and/or AA spray followed this descending order: "HA+AA2" > "HA+AA1" = AA2 > AA1 > HA. Regarding the response to gamma irradiation, 15Gy was $>30 \mathrm{~Gy}$. Farag and El-Khawaga (2013) reported that gamma irradiation of sesame and $\mathrm{N}$-application increased the 1000-seed weight. These results are in agreement with those of Sary et al. (2009) and Kandil et al. (2011).

The treatment of HA + AA2 irradiated with 15Gy gamma irradiation caused the highest increase in 100-seed weight (33.4\%).

Straw, pod and seed yields

The obtained results exhibited significant increases due to the applications of application foliar spray, irradiation and their combinations compared to the non-treated plants. Low gamma ray radiation increases enzymatic activation,

Egypt. J. Soil Sci. 55, No. 3 (2015) 
stimulating cell division, and germination as well as vegetative growth (Ashri, 2007). The favorable effect of ascorbic acid may be due to its role as a growth regulator that influences many physiological processes such as the synthesis of enzymes, nucleic acids, proteins and acts as co-enzyme (El-Greadly, 2002). Humic acids contain various bio-chemicals and growth promoting substances (phytohormones) which have favourable effect on cell wall membranes cytoplasm, including more photosynthesis and respirations rates in plants, enhanced protein synthesis and promote seed germination and root elongation (Chen and Aviad, 1990). Bakry et al. (2013) stated that the humic acid and ascorbic acid gave the highest straw and grain yield of wheat grown under newly reclaimed sandy soil.

Main effect shows the following order: "HA+AA1" > "HA+AA2" > AA2 > $\mathrm{HA}>\mathrm{AA} 1$ for straw yield; "HA+AA2" > "HA+AA1" > AA2 = HA > AA1 for seed yield and "HA+AA2" $\geq$ "HA+AA1" > AA2 = HA > AA1 for pod yield. As for the main effect of irradiation the order was: $15 \mathrm{~Gy}>30 \mathrm{~Gy}$. For pod yield, the main effect shows no significant difference.

TABLE 2. Yield components of soybean as affected by gamma irradiation and foliar applications.

\begin{tabular}{|c|c|c|c|c|c|c|c|c|c|c|}
\hline \multirow[b]{2}{*}{ Item } & \multirow[b]{2}{*}{$\begin{array}{c}\text { Gamma } \\
\text { dose } \\
\text { (G) }\end{array}$} & \multicolumn{9}{|c|}{ "Foliar application (F) } \\
\hline & & 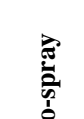 & 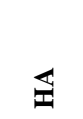 & $\sum$ & $\frac{1}{4}$ & 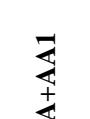 & $\sum_{+}^{2}$ & Mean & F-te & \\
\hline \multirow{4}{*}{$\begin{array}{l}\text { 100-seed } \\
\text { Weight } \\
\text { (g) }\end{array}$} & 0 & 59.5 & 63.1 & 61.5 & 62.5 & 63.2 & 64.6 & $62.4 \mathrm{c}$ & \multirow{4}{*}{$\begin{array}{c}\text { F: } \\
\text { G: } \\
\text { FxG: }\end{array}$} & \multirow{4}{*}{$\begin{array}{l}* * \\
* * \\
* *\end{array}$} \\
\hline & 15 & 67.9 & 72.6 & 68.3 & 71.6 & 73.7 & 79.4 & $72.2 \mathrm{a}$ & & \\
\hline & 30 & 62.2 & 71.1 & 65.2 & 69.9 & 70.4 & 73.5 & $68.7 \mathrm{~b}$ & & \\
\hline & Mean & $63.2 \mathrm{~d}$ & $68.9 \mathrm{~b}$ & $65.0 \mathrm{c}$ & $68.0 \mathrm{~b}$ & $69.1 \mathrm{~b}$ & $72.5 \mathrm{a}$ & 67.8 & & \\
\hline \multirow{4}{*}{$\begin{array}{l}\text { Straw yield } \\
\left(\mathrm{Mg} \mathrm{ha}^{-1}\right)\end{array}$} & 0 & 2.92 & 3.88 & 3.58 & 4.04 & 4.28 & 4.13 & $3.80 \mathrm{c}$ & \multirow{4}{*}{$\begin{array}{c}\text { F: } \\
\text { G: } \\
\text { FxG: }\end{array}$} & \multirow{4}{*}{$\begin{array}{l}* * \\
* * \\
* *\end{array}$} \\
\hline & 15 & 4.11 & 5.01 & 4.49 & 5.26 & 5.82 & 5.60 & $5.05 \mathrm{a}$ & & \\
\hline & 30 & 4.04 & 4.43 & 4.24 & 4.53 & 5.71 & 5.10 & $4.68 \mathrm{~b}$ & & \\
\hline & Mean & $3.69 \mathrm{f}$ & $4.44 \mathrm{~d}$ & $4.10 \mathrm{e}$ & $4.61 \mathrm{c}$ & $5.27 \mathrm{a}$ & $4.94 \mathrm{~b}$ & 4.51 & & \\
\hline \multirow{4}{*}{$\begin{array}{l}\text { Seed yield } \\
\left(\mathrm{Mg} \mathrm{ha}^{-1}\right)\end{array}$} & 0 & 1.14 & 1.52 & 1.17 & 1.39 & 1.77 & 1.85 & $1.47 \mathrm{c}$ & \multirow{4}{*}{$\begin{array}{c}\text { F: } \\
\text { G: } \\
\text { FxG: }\end{array}$} & \multirow{4}{*}{$\begin{array}{c}{ }^{* *} \\
* * \\
\text { NS }\end{array}$} \\
\hline & 15 & 1.76 & 2.64 & 1.96 & 2.56 & 2.85 & 2.92 & $2.45 \mathrm{a}$ & & \\
\hline & 30 & 1.71 & 2.36 & 1.69 & 2.42 & 2.69 & 2.99 & $2.31 \mathrm{~b}$ & & \\
\hline & Mean & $1.53 \mathrm{~d}$ & $2.17 \mathrm{c}$ & $1.60 \mathrm{~d}$ & $2.12 \mathrm{c}$ & $2.44 \mathrm{~b}$ & $2.58 \mathrm{a}$ & 2.08 & & \\
\hline \multirow{4}{*}{$\begin{array}{l}\text { Pod yield } \\
\left(\mathrm{Mg} \mathrm{ha}^{-1}\right)\end{array}$} & 0 & 1.34 & 2.37 & 1.54 & 1.75 & 2.14 & 2.55 & $1.95 \mathrm{~b}$ & \multirow{4}{*}{$\begin{array}{c}\text { F: } \\
\text { G: } \\
\text { FxG: }\end{array}$} & \multirow{4}{*}{$\begin{array}{c}{ }^{* *} \\
{ }^{* *} \\
\text { NS }\end{array}$} \\
\hline & 15 & 1.97 & 3.24 & 2.56 & 3.17 & 3.58 & 3.87 & $3.07 \mathrm{a}$ & & \\
\hline & 30 & 1.95 & 3.06 & 2.36 & 2.90 & 3.26 & 3.46 & $2.83 \mathrm{a}$ & & \\
\hline & Mean & $1.75 \mathrm{~d}$ & $2.89 \mathrm{~b}$ & $2.15 \mathrm{c}$ & $2.61 \mathrm{~b}$ & $2.99 \mathrm{ab}$ & $3.29 \mathrm{a}$ & 2.61 & & \\
\hline
\end{tabular}

${ }^{*} \mathrm{HA}$ : humic acid (2000 $\left.\mathrm{mg} \mathrm{L}^{-1}\right)$, AA1: $300 \mathrm{mg} \mathrm{L}^{-1}$ ascorbic acid, AA2: $600 \mathrm{mg} \mathrm{L}^{-1}$ ascorbic acid 
The highest straw and pod yields of 5.82 and $3.87 \mathrm{Mg} \mathrm{ha}^{-1}$, respectively were achieved due to application of $\mathrm{HA}+\mathrm{AA} 1$ and $\mathrm{HA}+\mathrm{AA} 2$, respectively when irradiated with $15 \mathrm{~Gy}$ gamma ray and the corresponding increments over the non-treated plants were 99 and $188 \%$, respectively. The highest seed yield of $2.99 \mathrm{Mg} \mathrm{ha}^{-1}$ was observed due to addition of HA + AA2 with 30Gy gamma ray irradiation giving an increase of $162 \%$ over the non-treated.

\section{Pod shelling percentage}

Shelling percentage as influenced by foliar applications and gamma irradiation is illustrated in Fig.1. Plants which received foliar spray with HA and/or AA solely or in combination showed slight decreases. Ibrahim and Eleiwa (2008) reported that NPK increased shelling percentage of groundnut. The obtained results are in full agreement with those obtained by Hossain et al. (2007). Ali and Mowafy (2003) pointed out that adding K fertilizer increased shelling percentage of peanut. The spray treatments under $15 \mathrm{~Gy}$ can be arranged in the following order: non-sprayed $>\mathrm{HA}>\mathrm{AA} 2>\mathrm{HA}+\mathrm{AA} 1>\mathrm{AA} 1$ $>\mathrm{HA}+\mathrm{AA} 2$. Under 30 Gy irradiation the order is: non-sprayed > HA+AA2 > $\mathrm{AA} 2>\mathrm{HA}+\mathrm{AA} 1>\mathrm{HA}>\mathrm{AA} 1$.

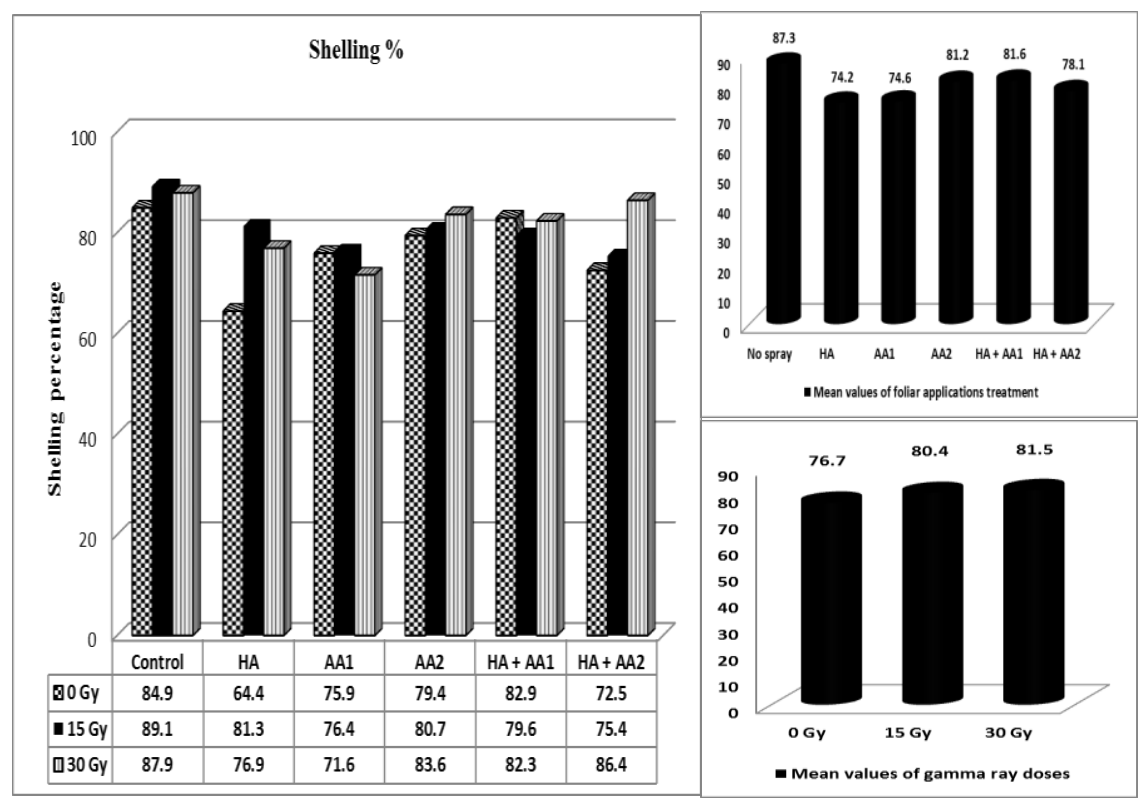

Gamma irradiation dosed, i.e. 0, 15 and $30 \mathrm{~Gy}$

Fig.1. Shelling percentage of soybean as affected by gamma irradiation and foliar spray with humic and ascorbic acids.

\section{Seed Quality}

Seed protein content and seed protein yield

Results presented in Table 3 show that protein content and protein yield of soybean seeds significantly increased owing to foliar spray and gamma

Egypt. J. Soil Sci. 55, No. 3 (2015) 
irradiation, foliar spraying with HA and AA. The highest increases in protein content $(27 \%)$ as well as protein yield $\left(851 \mathrm{~kg} \mathrm{ha}^{-1}\right)$ were recorded in the plants treated with HA + AA2 + 15Gy. Rahimi and Abdallah (2011) stated that gamma irradiation of wheat seeds (25 and $50 \mathrm{~Gy}$ ) increased protein content of grains. Gad El-Hak et al. (2012) found that foliar spray with HA and AA to peas protein content in seeds. The current results are in agreement with those reported by Morard et al. (2011) who reported positive response to HA spray on various plants. The main effect of irradiation shows increases and that $15 \mathrm{~Gy}$ was superior to $30 \mathrm{G}$. As for foliar spray, the main effect shows increases with a descending order of: $\mathrm{HA}+\mathrm{AA} 2>\mathrm{HA}+\mathrm{AA} 1>\mathrm{HA}>\mathrm{AA} 1>\mathrm{AA} 2$ for protein content; and: $\mathrm{HA}+\mathrm{AA} 2>\mathrm{HA}+\mathrm{AA} 1>\mathrm{HA}>\mathrm{AA} 2>\mathrm{AA} 1$ for protein yield.

TABLE 3. Protein content of soybean seeds as affected by gamma irradiation and foliar applications.

\begin{tabular}{|c|c|c|c|c|c|c|c|c|c|c|}
\hline \multirow[b]{2}{*}{ Item } & \multirow[b]{2}{*}{$\begin{array}{c}\text { Gamma } \\
\text { dose } \\
(\mathbf{G})\end{array}$} & \multicolumn{9}{|c|}{ * Foliar application (F) } \\
\hline & & $\begin{array}{l}\overrightarrow{7} \\
\frac{0}{0} \\
\text { के } \\
\dot{0}\end{array}$ & 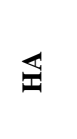 & $\frac{7}{4}$ & $\sum^{2}$ & $\begin{array}{l}\sum_{1} \\
\pm \\
\pm\end{array}$ & $\sum_{\substack{1 \\
\pm}}^{N}$ & Mean & F-tes & \\
\hline \multirow{4}{*}{$\begin{array}{l}\text { Protein } \\
\text { content } \\
\left(\mathrm{g} \mathrm{kg}^{-1}\right)\end{array}$} & 0 & 230 & 224 & 231 & 216 & 229 & 239 & $228 \mathrm{~b}$ & \multirow{4}{*}{$\begin{array}{c}\text { F: } \\
\text { G: } \\
\text { FxG: }\end{array}$} & \multirow{4}{*}{$\begin{array}{l}* * \\
* * \\
* *\end{array}$} \\
\hline & 15 & 218 & 254 & 235 & 234 & 275 & 292 & $251 \mathrm{a}$ & & \\
\hline & 30 & 201 & 238 & 230 & 229 & 243 & 253 & $232 \mathrm{~b}$ & & \\
\hline & Mean & $216 \mathrm{f}$ & $239 c$ & $232 \mathrm{~d}$ & $227 \mathrm{e}$ & $249 b$ & $261 \mathrm{a}$ & 237 & & \\
\hline \multirow{4}{*}{$\begin{array}{l}\text { Protein yield } \\
\left(\mathrm{kg} \mathrm{ha}^{-1}\right)\end{array}$} & 0 & 261 & 341 & 269 & 301 & 405 & 441 & $336 \mathrm{c}$ & \multirow{4}{*}{$\begin{array}{c}\text { F: } \\
\text { G: } \\
\text { FxG: }\end{array}$} & \multirow{4}{*}{$\begin{array}{l}* * \\
* * \\
* *\end{array}$} \\
\hline & 15 & 382 & 670 & 460 & 598 & 785 & 851 & $624 \mathrm{a}$ & & \\
\hline & 30 & 344 & 560 & 388 & 555 & 653 & 756 & $542 \mathrm{~b}$ & & \\
\hline & Mean & $329 \mathrm{f}$ & $523 c$ & $372 \mathrm{e}$ & $485 \mathrm{~d}$ & $614 b$ & $683 a$ & 501 & & \\
\hline
\end{tabular}

See footnote of Table 2

Regarding the seed protein yield, results followed the trend almost the same of protein content. This could be attributed to the organic acids which are known as a growth regulator factor that influence many physiological processes such as the synthesis of enzymes, nucleic acids, proteins and act as co-enzymes. Also, the integrated effect of humic acid and bio effect of microorganisms on increasing available nutrients for plant growth and accordingly maximizing the biological yield and grain quality (Ewees and Abdel Hafeez, 2010). Bakry et al. (2013) pointed out that foliar application of humic acid and/or ascorbic acid and their combinations shows significant differences and gave the highest protein $\%$ and protein yield of wheat grown under newly reclaimed sandy soil.

Seed oil content and seed oil yield

As illustrated in Fig. 2 and 3, seed oil content and seed oil yield increased due to irradiation and foliar spray with HA and/or AA. The increase ranged from 273 to $381 \mathrm{~g} \mathrm{~kg}^{-1}$. The highest seed oil content and oil yield values of 381 $\mathrm{g} \mathrm{kg}^{-1}$ and $1111 \mathrm{~kg} \mathrm{ha}^{-1}$, respectively were obtained as by HA + AA2 in 
combination with $15 \mathrm{Gr}$ gamma irradiation, with increases of $40 \%$ and $258 \%$, respectively. The oil content from soybean seed determined in this study is higher than $208 \mathrm{~g} \mathrm{~kg}^{-1}$ reported in soybean grown in Nigeria and lower than 441 $\mathrm{g} \mathrm{kg}^{-1}$ reported in soybean grown in Turkey (Cecil et al., 2013). Differences in such property among different regions are attributed to variations in varieties, farming environment, ripening stage, harvesting time, and extraction methods. The oil content of soybean seeds in the present study is higher than contents in seeds of other oil seed crops such as: cotton (150-240 $\left.\mathrm{g} \mathrm{kg}^{-1}\right)$, but within the range of those of mustard seeds $\left(240-400 \mathrm{~g} \mathrm{~kg}^{-1}\right)$ and safflower seeds $\left(250-400 \mathrm{~g} \mathrm{~kg}^{-}\right.$ $\left.{ }^{1}\right)$, (Pritchard, 1991). Main effect of foliar spray shows the following order: $\mathrm{HA}+\mathrm{AA} 2>\mathrm{HA}+\mathrm{AA} 1 \geq \mathrm{HA}>\mathrm{AA} 2>\mathrm{AA} 1>$ non-sprayed for oil content; and $\mathrm{HA}+\mathrm{AA} 2>\mathrm{HA}+\mathrm{AA} 1>\mathrm{HA}>$ non-sprayed $>\mathrm{AA} 1$ for oil yield.

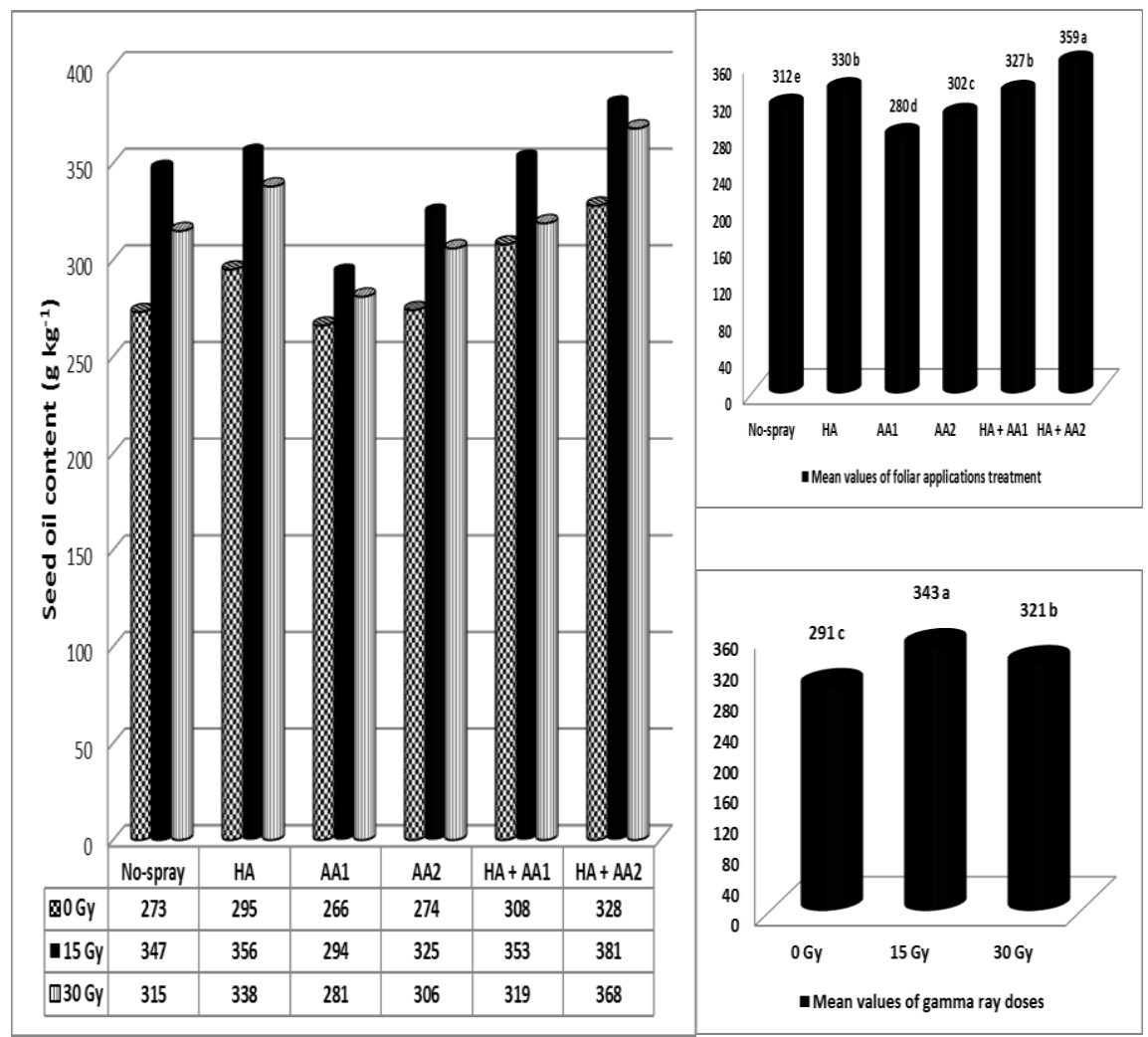

Fig. 2. Oil content, $\mathrm{g} \mathrm{kg}^{-1}$ of soybean as affected by gamma irradiation and foliar applications. 


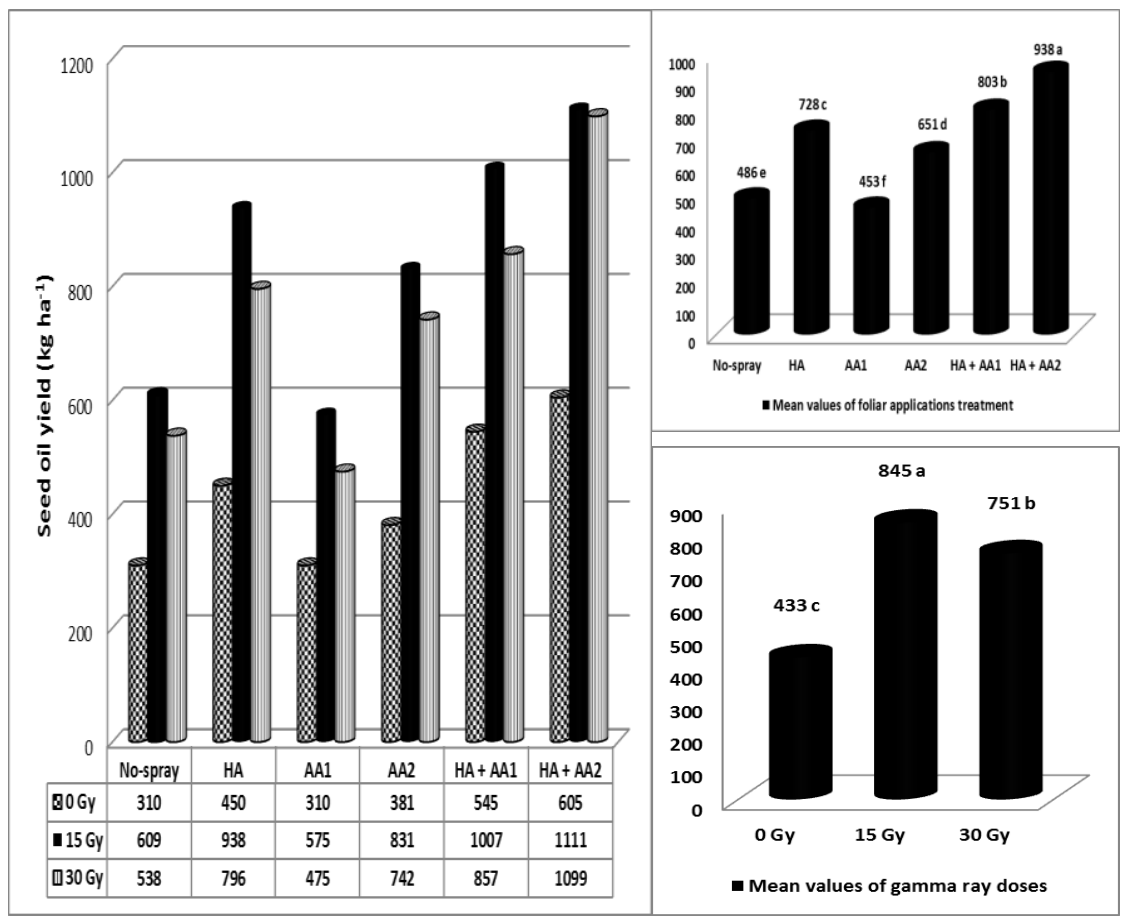

Fig. 3. Oil yield, $\mathrm{kg} \mathrm{ha}^{-1}$ of soybean as affected by gamma irradiation and foliar applications.

\section{$N, P$ and $K$ content and uptake}

The results shown in Tables 4, 5 and 6 reveal that N, P and $\mathrm{K}$ content and uptake in soybean straw and seeds increased due to foliar spray and seed irradiation. Gamma irradiation was reported by Xienia et al. (2000) to induce oxidative stress with overproduction of reactive oxygen species such as superoxide radicals $\left(\mathrm{O}_{2}^{-}\right)$, hydroxyl radicals $\left(\mathrm{OH}^{-}\right)$and hydrogen peroxide $\left(\mathrm{H}_{2} \mathrm{O}_{2}\right)$, which react rapidly with almost all structural and functional organic molecules, including proteins, lipids and nucleic acids. According to Rima et al. (2011) humic substances may enhance uptake of nutrients through stimulation of soil microbiological activity. In other words, HA application could be a hormone substance enhancing root development and proliferation. Ascorbic acid is synthesized in higher plants and enhances their plant growth and development of D-glucose metabolism which affects nutritional activity and plays an important role in electron transport systems (El-Kobisy et al., 2005). Results obtained in the current study are similar to those reported by Habashy (2005) on peanut and faba bean, Zaky et al. (2006) on faba beans; Abdel Aziz et al. (2009) on gladiolus; El-Hefny (2010) on cowpea, Morard et al. (2011) and Gad El-Hak et al. (2012) on peas, Bakry et al. (2013) and Abd El-Hamid et al. (2013) on wheat and Helmy (2014) on barley. 
Nitrogen content and uptake

The results shown in Table 4 reveal positive response to spray and seed irradiation. The highest $\mathrm{N}$ contents in seed and straw of 51.1 and $29.1 \mathrm{~g} \mathrm{~kg}^{-1}$, respectively were produced by $\mathrm{HA}+\mathrm{AA} 2$ with $15 \mathrm{Gr}$ gamma irradiation as compared with $40.3 \mathrm{~g} \mathrm{~kg}^{-1}$ and $21.3 \mathrm{~g} \mathrm{~kg}^{-1}$ in seeds and straw, respectively for the non-treated. Highest $\mathrm{N}$ uptake in seeds and straw of 149 and $163 \mathrm{~kg} \mathrm{ha}^{-1}$, respectively were obtained by HA + AA2 with $15 \mathrm{~Gy}$ causing increases of $225 \%$ and $162 \%$, respectively. Spraying with $\mathrm{HA}$ and AA shows the following pattern: $15 \mathrm{~Gy}>30 \mathrm{~Gy}$ for $\mathrm{N}$ content and uptake. Main effects indicate seeds and straw; $\mathrm{HA}+\mathrm{AA} 2>\mathrm{HA}+\mathrm{AA} 1>\mathrm{HA}>\mathrm{AA} 1>\mathrm{AA} 2$ for $\mathrm{N}$ content in seeds; $\mathrm{HA}+\mathrm{AA} 2>\mathrm{HA}+\mathrm{AA} 1>\mathrm{HA}>\mathrm{AA} 2>\mathrm{AA} 1$ for $\mathrm{N}$ uptake in seeds; HA+AA2 > $\mathrm{HA}+\mathrm{AA} 1>\mathrm{HA}=\mathrm{AA} 1=\mathrm{AA} 2$ for $\mathrm{N}$-content in straw; and $\mathrm{HA}+\mathrm{AA} 2 \geq$ $\mathrm{HA}+\mathrm{AA} 1>\mathrm{AA} 2>\mathrm{HA}>\mathrm{AA} 1$ for $\mathrm{N}$ uptake in straw.

TABLE 4. $\mathrm{N}$ content $\left(\mathrm{g} \mathrm{kg}^{-1}\right)$ and $\mathrm{N}$-uptake $\left(\mathrm{kg} \mathrm{ha}^{-1}\right)$ of soybean as affected by gamma irradiation and foliar applications

\begin{tabular}{|c|c|c|c|c|c|c|c|c|c|c|c|}
\hline \multirow{2}{*}{\multicolumn{2}{|c|}{ Item }} & \multirow[b]{2}{*}{$\begin{array}{c}\text { Gamma } \\
\text { dose } \\
(\mathbf{G})\end{array}$} & \multicolumn{9}{|c|}{ * Foliar application (F) } \\
\hline & & & 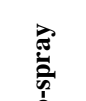 & 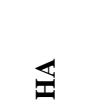 & $\sum$ & $\sum$ & $\sum_{t}$ & $\sum_{t}^{N}$ & Mean & \multicolumn{2}{|c|}{ F-test } \\
\hline \multirow{8}{*}{ Seeds } & \multirow{4}{*}{$\begin{array}{c}\mathbf{N} \\
\text { content, } \\
\text { g kg }^{-1}\end{array}$} & 0 & 40.3 & 39.2 & 40.4 & 37.9 & 40.1 & 41.9 & $40.0 \mathrm{~b}$ & \multirow{4}{*}{$\begin{array}{c}\text { F: } \\
\text { G: } \\
\text { FxG: }\end{array}$} & \multirow{4}{*}{$\begin{array}{l}* * \\
* * \\
* *\end{array}$} \\
\hline & & 15 & 38.1 & 44.5 & 41.2 & 41.0 & 48.2 & 51.1 & $44.0 \mathrm{a}$ & & \\
\hline & & 30 & 35.2 & 41.6 & 40.2 & 40.1 & 42.6 & 44.3 & $40.7 \mathrm{~b}$ & & \\
\hline & & Mean & $37.9 \mathrm{f}$ & $41.8 \mathrm{c}$ & $40.6 \mathrm{~d}$ & $39.7 \mathrm{e}$ & $43.6 \mathrm{~b}$ & $45.8 \mathrm{a}$ & 41.6 & & \\
\hline & \multirow{4}{*}{$\begin{array}{c}\text { N- } \\
\text { uptake, } \\
\text { kg ha }^{-1}\end{array}$} & 0 & 45.8 & 59.8 & 47.1 & 52.7 & 70.9 & 77.4 & $58.9 \mathrm{c}$ & \multirow{4}{*}{$\begin{array}{c}\text { F: } \\
\text { G: } \\
\text { FxG: }\end{array}$} & \multirow{4}{*}{$\begin{array}{l}* * \\
* * \\
* *\end{array}$} \\
\hline & & 15 & 66.9 & 117 & 80.5 & 105 & 137 & 149 & $109 \mathrm{a}$ & & \\
\hline & & 30 & 60.2 & 98.1 & 68.0 & 97.3 & 114 & 132 & $95.6 \mathrm{~b}$ & & \\
\hline & & Mean & $57.6 \mathrm{f}$ & $91.7 \mathrm{c}$ & $65.2 \mathrm{e}$ & $85.0 \mathrm{~d}$ & $107 \mathrm{~b}$ & $120 \mathrm{a}$ & 87.8 & & \\
\hline \multirow{8}{*}{ Straw } & \multirow{4}{*}{$\begin{array}{c}\mathrm{N} \\
\text { content, } \\
\mathrm{g} \mathrm{kg}^{-1}\end{array}$} & 0 & 21.3 & 18.9 & 19.3 & 18.7 & 22.4 & 24.2 & $20.8 \mathrm{~b}$ & \multirow{4}{*}{$\begin{array}{c}\text { F: } \\
\text { G: } \\
\text { FxG: }\end{array}$} & \multirow{4}{*}{$\begin{array}{c}* * \\
* * \\
*\end{array}$} \\
\hline & & 15 & 20.4 & 21.7 & 20.7 & 22.5 & 26.4 & 29.1 & $23.5 \mathrm{a}$ & & \\
\hline & & 30 & 18.8 & 19.4 & 19.6 & 21.1 & 23.8 & 25.7 & $21.4 \mathrm{~b}$ & & \\
\hline & & Mean & $20.2 \mathrm{c}$ & $20.0 \mathrm{c}$ & $19.9 \mathrm{c}$ & $20.8 \mathrm{c}$ & $24.2 \mathrm{~b}$ & $26.3 \mathrm{a}$ & 21.9 & & \\
\hline & \multirow{4}{*}{$\begin{array}{c}\text { N- } \\
\text { uptake, } \\
\text { kg ha }^{-1}\end{array}$} & 0 & 62.2 & 73.3 & 69.2 & 75.5 & 95.8 & 99.9 & $79.3 \mathrm{c}$ & \multirow{4}{*}{$\begin{array}{c}\text { F: } \\
\text { G: } \\
\text { FxG: }\end{array}$} & \multirow{4}{*}{$\begin{array}{l}* * \\
* * \\
\mathrm{NS}\end{array}$} \\
\hline & & 15 & 83.9 & 109 & 92.9 & 118 & 154 & 163 & $120 \mathrm{a}$ & & \\
\hline & & 30 & 75.9 & 85.9 & 83.1 & 95.6 & 136 & 131 & $101 \mathrm{~b}$ & & \\
\hline & & Mean & $74.0 \mathrm{~d}$ & $89.3 \mathrm{bc}$ & $81.7 \mathrm{c}$ & $96.4 \mathrm{~b}$ & $129 \mathrm{a}$ & $131 \mathrm{a}$ & 100 & & \\
\hline
\end{tabular}

See footnote of Table 2

\section{Phosphorus content and uptake}

Table 5 clarifies the content and uptake of $\mathrm{P}$ in soybean seed and straw as affected by the tested treatment. Phosphorus content and uptake by soybean seeds and straw increased as a result of foliar spray and seed irradiation. The highest $\mathrm{P}$ content of $6.56 \mathrm{~g} \mathrm{~kg}^{-1}$ in seeds and $3.98 \mathrm{~g} \mathrm{~kg}^{-1}$ in straw was by $\mathrm{HA}+\mathrm{AA} 2$ and $\mathrm{HA}+\mathrm{AA} 1$, respectively with $15 \mathrm{~Gy}$ as compared with 3.02 and Egypt. J. Soil Sci. 55, No. 3 (2015) 
$2.22 \mathrm{~g} \mathrm{~kg}^{-1}$ in seeds and straw, respectively for the untreated. The highest Puptake of $19.1 \mathrm{~kg} \mathrm{ha}^{-1}$ in seeds was by HA + AA2 with 15 Gy while the highest $\mathrm{P}$-uptake of $23.3 \mathrm{~kg} \mathrm{ha}^{-1}$ in straw was by HA+AA1; with respective increases of $457 \%$ and $258 \%$.

The individual effect of gamma irradiation showed pronounced increases of $15 \mathrm{~Gy}$ than $30 \mathrm{~Gy}$ for $\mathrm{P}$ content in seed and straw and its uptake. The main effect of foliar applications followed the sequence: HA+AA2 $>$ HA+AA1 $>$ AA2 $\geq$ AA1 $\geq \mathrm{HA}$ for $\mathrm{P}$ content in seeds and $\mathrm{HA}+\mathrm{AA} 2>\mathrm{HA}+\mathrm{AA} 1>\mathrm{AA} 2 \geq \mathrm{AA} 1>\mathrm{HA}$ for $\mathrm{P}$-uptake in seeds, respectively. In straw the pattern was: $\mathrm{HA}+\mathrm{AA} 2 \geq \mathrm{HA}+\mathrm{AA} 1$ $>\mathrm{AA} 2 \geq \mathrm{AA} 1>\mathrm{HA}$ for $\mathrm{P}$ content and $\mathrm{HA}+\mathrm{AA} 2 \geq \mathrm{HA}+\mathrm{AA} 1>\mathrm{AA} 2>\mathrm{AA} 1 \geq$ $\mathrm{HA}$ for P-uptake. The main effect regarding irradiation shows $15 \mathrm{~Gy}>30 \mathrm{~Gy}$ for content and uptake, in seeds as well as straw.

TABLE 5. $P$ content $\left(\mathrm{g} \mathrm{kg}^{-1}\right)$ and $P$-uptake $\left(\mathrm{kg} \mathrm{ha}^{-1}\right)$ of soybean as affected by gamma irradiation and foliar applications.

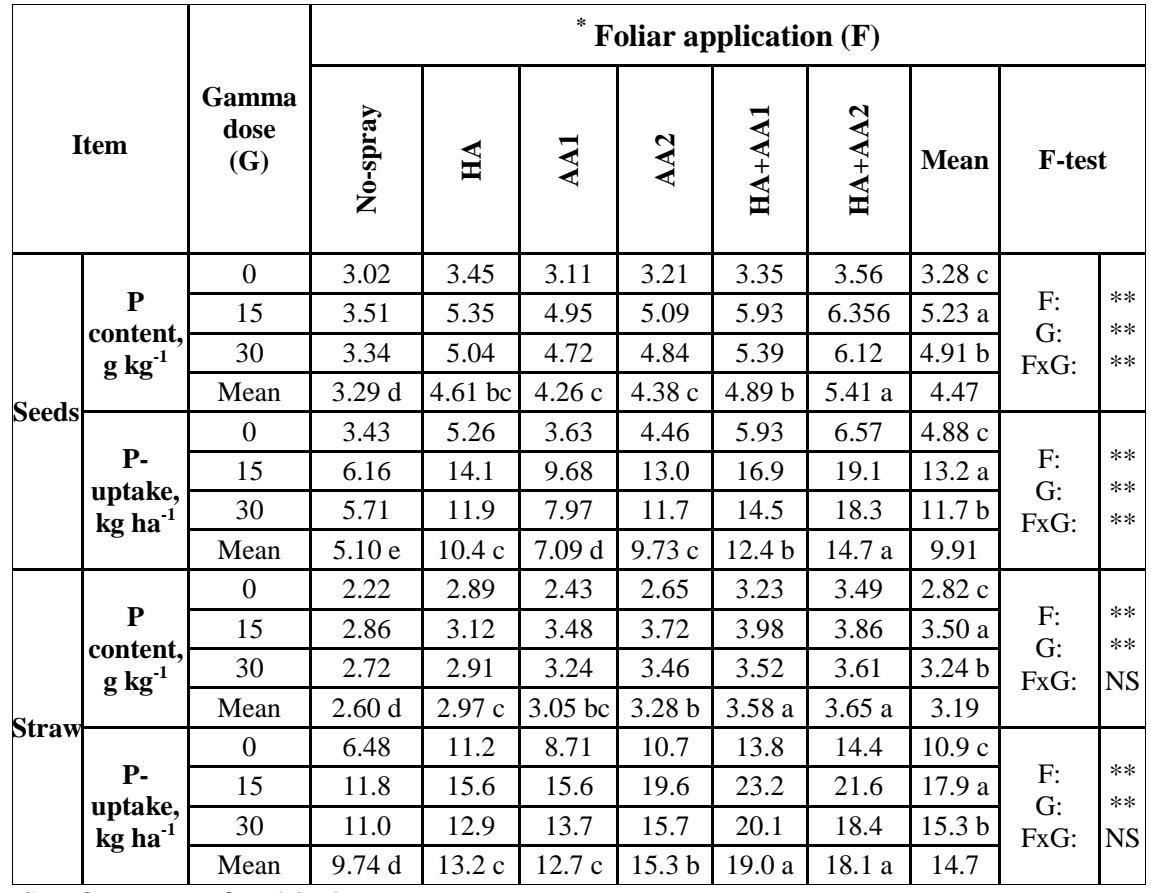

See footnote of Table 2

\section{Potassium content and uptake}

As shown in Table 6, $\mathrm{K}$ content and uptake in seeds and straw increased owing to foliar spray and seed irradiation with exception of $\mathrm{K}$ content in straw which was insignificantly affected by irradiation. Highest $\mathrm{K}$ contents of $16.8 \mathrm{~g}$ $\mathrm{kg}^{-1}$ in seeds was by HA + AA2 with $15 \mathrm{~Gy}$, and highest content of $35.4 \mathrm{~g} \mathrm{~kg}^{-1}$ in straw was by HA+AA1 with $15 \mathrm{~Gy}$. Highest $\mathrm{K}$ uptake of $49.0 \mathrm{~kg} \mathrm{ha}^{-1}$ in seeds 
was due to $\mathrm{HA}+\mathrm{AA} 2$ and highest $\mathrm{K}$ uptake of $206 \mathrm{~kg} \mathrm{ha}^{-1}$ in straw was by $\mathrm{HA}+\mathrm{AA} 1$; with respective increases of $159 \%$ and $325 \%$.

TABLE 6. $\mathrm{K}$ content, $\mathrm{g} \mathrm{kg}^{-1}$ and $\mathrm{K}$-uptake, $\mathrm{kg} \mathrm{ha}^{-1}$ of soybean as affected by gamma irradiation and foliar applications.

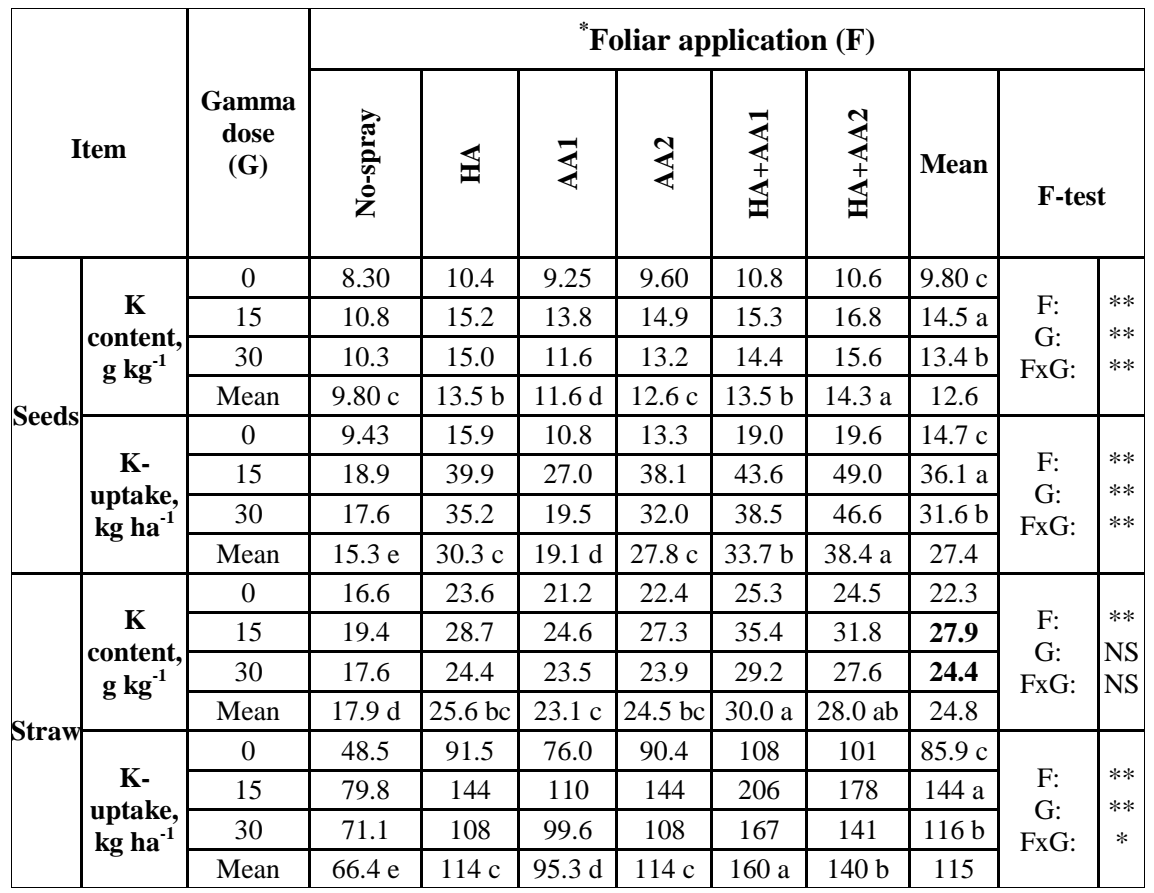

See footnote of Table 2

The main effect of foliar spray shows: $\mathrm{HA}+\mathrm{AA} 2>\mathrm{HA}+\mathrm{AA} 1 \geq \mathrm{HA}>\mathrm{AA} 2>$ $\mathrm{AA} 1$ for $\mathrm{K}$ content in seed and $\mathrm{HA}+\mathrm{AA} 2>\mathrm{HA}+\mathrm{AA} 1>\mathrm{HA} \geq \mathrm{AA} 2>\mathrm{AA} 1$ for $\mathrm{K}$-uptake by seed; $\mathrm{HA}+\mathrm{AA} 1 \geq \mathrm{HA}+\mathrm{AA} 2>\mathrm{HA} \geq \mathrm{AA} 2 \geq \mathrm{AA} 1$ for $\mathrm{K}$ content by straw and $\mathrm{HA}+\mathrm{AA} 1>\mathrm{HA}+\mathrm{AA} 2>\mathrm{HA}=\mathrm{AA} 2>\mathrm{AA} 1$ for $\mathrm{K}$ uptake by straw. The main effect for irradiation shows $15 \mathrm{~Gy}>30 \mathrm{~Gy}$ for contents as well as uptake of $\mathrm{K}$ in seeds and straw.

\section{Conclusion}

The obtained results reveal that foliar spray of soybean plants with humic acid and/or ascorbic acid antioxidants is beneficial to crop growth, yield components and nutrient uptake. Also, seed irradiated with 15 or $30 \mathrm{~Gy}$ gamma ray showed positive results. The $15 \mathrm{~Gy}$ was superior to the $30 \mathrm{~Gy}$ treatment. Hence, it could be suggested that soybean plants grown may be sprayed with ascorbic acid at 300 or $600 \mathrm{mg} \mathrm{L}^{-1}$ and humic acid at $2000 \mathrm{mg} \mathrm{L}^{-1}$ to enhance growth and nutrient uptake as well as improve the quantity and quality of soybean when seeds were exposed to 15 Gy gamma rays before planting. This

Egypt. J. Soil Sci. 55, No. 3 (2015) 
may reduce requirements of chemical fertilizers with no toxic substances accumulating or injurious radiation in the food chain.

\section{Refrences}

Abdel Aziz, G.N., Tamer, L. and Ibrahim, S.M. (2009) Some studies on the effect of putrescine, ascorbic acid and thianine on growth, flowering and some chemical constituents, of gladiolus plants at Nubaria. Ozean J. Appl. Sci. 2(2), 169 - 179.

Abd El-Hamid, A.R., Al-Kamar, F.A.A. and Husein, M.E. (2013) Impact of some organic and biofertilizers soil amendments on the fertility status, some soil properties and productivity of sandy soil. J. Soil Sci. Agric. Eng., Mansoura Univ. 4 (10), 989 - 1007.

Ali, A.A.G. and Mowafy, S.A.E. (2003) Effect of different levels of potassium and phosphorus fertilizers with the foliar application of zinc and boron on peanut in sandy soils. Zagazig J. Agric. Res . 30 (20), 335 - 358

A.O.A.C. (1990) "Official Methods of Analysis". Association of Official Analytical, Arlington, Virgina, USA

Ashri, A. (2007) Sesame (Sesamum indicum L.). In: "Oilseed Crops" : R.J. Singh, Ed. Genetics resources chromosome engineering, and crop improvement. pp. $231-289$, CRC Press, Boca Raton, Fl, USA.

Asik, B.B., Turan, M.A., Celik H. and Katkat, A.V. (2009) Effect of humic substances on plant growth and mineral nutrients uptake of wheat (Triticium durum cv. Salihi) under of salinity. Asian J. Crop Sci. (1), $87-95$.

Bakry, B.A., Elewa, T.A., El-Kramany, M.F. and Wali, A.M. (2013) Effect of humic and ascorbic acids foliar application on yield and yield components of two wheat cultivars grown under newly reclaimed sandy soil. Inter. J. Agron. and Plant Production, 4 (6), 1125 - 1133.

Black, C.A. (1965) "Methods of soil Analysis I \&II". Amer . Soc . Agron . Inc , Publisher, Madison, Wisconsin, USA.

Cecil, F., Anwar, F., Shahid, S.A. and Ahmad, N. (2013) Comparison of physicochemical properties between two varieties of peanut (Arachis hypogaea L.) seed oil from Pakistan. Asian J. Chem. 25, 3271-3274

Chapman, H.D. and Paratt, P.F. (1961) "Methods of Analysis for Soil Plants and Waters". Agric. Publ. Univ., of California, Riverside, USA.

Chen, Y. and Aviad, T. (1990) In: "Effects of Humic Substances on Plant Growth". McCarthy, P., Calpp, C.E. and Malcolm, A.S.A. and SSSA, Madison, WI., pp: 161 186.

El-Agroudy, N., Mohamed, S., Ezzat, A.Z. and Mahmoud, E. (2011) An economic study of the production of soybean in Egypt. Agric. Biol. J. N. Am. 2 (2), $221-225$. 
El-Greadly, N.H.M. (2002) Effect of foliar application of ascorbic acid, ethereal and their combination on growth yield and endogenous hormones in cucmber plants. $J$. Agric Sci., Mansoura Univ., 27(8), 5269 - 5281.

El-Hefny, E.M. (2010) Effect of saline irrigation water and humic acid application on growth and productivity of two cultivars of cowpea (Vigna unguiculata L. Walp.). Australian J. Basic Appl. Sci. 4, $6154-6168$.

El-Kobisy, D.S., Kady, K.A., Medani, R.A. and Agamy, R.A. (2005) Response of pea plant (Pisum sativum L.) to treatment with ascorbic acid. Egypt J. Appl. Sci. 20, 36 59.

Ewees, M.S.A. and Abdel Hafeez, A.A.A. (2010) Response of Maize grain to a partial substitution of $\mathrm{N}$-mineral by applying organic manure, bio-inoculation and elemental sulphur as an alternative strategy to avoid the possible chemical pollution. Egypt. J. Soil Sci., 50 (1), 141 - 166.

FAO (2003) Food energy-methods of analysis and conversion factors. Report of a Technical Workshop. Food and Nutrition Paper, 77: Rome, 3 - 6 December, 2002 pp $7-11$

FAO, (2013) "Food and Agric. Organization of the United Nations Statistical". Statistical Year Book.

Farag, I.A.A. and El-Khawaga, A.A.H. (2013). Response of sesame to gamma irradiation and nitrogen fertilizer levels on newly reclaimed sandy soils. Zagazig $J$. Agric. Res. 39 (6), 1083 - 1092.

Gad El-Hak, S.H., Ahmed A.M. and Moustafa, Y.M.M. (2012). Effect of foliar application with two antioxidants and humic acid on growth, yield and yield components of peas (Pisum sativum L.). J. Hort. Sci. Ornamental Plants, 4 (3), 318 328.

Galal, A.A., Gad El-Hak, S.H. Abdel-Ati, Y.Y. and Moustafa, Y.M.M. (2000) Response of new tomato hybrids to some antioxidants and early blight. The $2^{\text {nd }}$ Scientific Conference of Agric. Sci., Assuit, Egypt.

Habashy, N.R., Ragab, A.A.M. and Abd El-Rasoul, Sh. (2005) Effect of some bioorganic amendments on a sequence cropping pattern of peanut-faba bean grown on a sandy soil. Egypt. J. Appl. Sci., 20, 752 - 763.

Helmy, A.M. (2014) Response of seed irradiation with gamma ray, N-fertilization and bio fertilization of barley (Hordeum vulgare L.) grown on a sand soil. J. Soil Sci. Agri. Eng., Mansours Univ., 5(1), 1 - 18.

Hossain, M.A., Hamid, A. and Nasreen, S. (2007) Effect of nitrogen and phosphorus fertilizer on N/P uptake and yield performance of groundnut (Arachis hypogaea L.). J. Agric. Res., 45(2), $119-127$.

Ibrahim, S.A. and Eleiwa, M.E. (2008) Response of groundnut (Arachis hypogaea L.) plants to foliar feeding with some organic manure extracts under different levels of NPK fertilizers. World J. Agric. Sci. 4(2), $140-148$.

Egypt. J. Soil Sci. 55, No. 3 (2015) 
Jyoti, P.M., Sukalyan, C.S.K., Subrata, P., Jiin-Shuh, J., Alok, C., Anindita, C. and Subhas, C.S. (2009) Effects of gamma irradiation on edible seed protein, amino acids and genomic DNA during sterilization. Food Chem., 114, 1237 - 1244.

Kandil, A.A., El-Hindi, M.H., Badawi, M.A., El Morarsy, S.A. and Kalboush, F.A.H.M. (2011) Response of wheat to rates of nitrogen, biofertilizers and land leveling. Crop \& Enviro. 2 (1), 46-51.

Kiong, A., Ling Pick, A., Grace, S.H., and Harun, A.R. (2008) Physiological responses of Orthosiphon stamineus plants to gamma irradiation. Am. Eurasian J. Sustain. Agric., 2(2), $135-149$.

Kovacs, E. and Keresztes, A. (2002) Effect of gamma irradiation and UV-B/C radiation on plant cell. Micron., 33, $199-210$.

Lindsay, W.L. and Norvell, W.A. (1978) Development of a DTPA soil test for Zn, Mn, Fe and Cu. Soil Sci. Soc. Am. J. 24 (2), $421-428$

Mahmoud, A.A. (2006) sustaining the quality and quantity of peanut productivity through out complementarily treatments between biogas manure, bio, and chemical fertilizers. Egypt. J. Appl. Sci., 21(9), 262- 280.

Magdi, T.A., Selim, E.M. and El-Ghamry, A.M. (2011) Integrated effects of bio and mineral fertilizers and humic substances on growth yield and nutrient contents of fertigated cowpea (Vigna unguiculata L.). J. Agron. 10 (1), 34 - 39.

Morard, P., Eyheraguibel, B., Morard, M. and Silvestre, J. (2011) Direct effects of humic-like substance on growth, water, and mineral nutrition of various species. $J$. Plant Nutr., 34(1), 46 - 59.

Page, A.L, Miller, R.H. and Keeney, D.R. (1982) "Methods of Soil Analysis. Part 2 Chemical and Microbiological Properties". Second Edition Agronomy Series 9. ASA 555A, Madison. Wis., USA.

Pritchard, J.L.R. (1991) Analysis and Properties of Oilseeds, In: J.B. Rossell and J.L.R. Pritchard,(Ed.) pp. 80 - 98. Analysis of Oilseeds, Fats and Fatty Foods, Elsevier Appl. Sci., New York,

Rahimi, M.M. and Abdallah, B. (2011) Influence of gamma irradiation on some physiological characteristics and grain protein in wheat (Triticum aestivum L.) World Applied Sci. J. 15 (5), 654 - 659.

Rima, J.A.H., Martin, S.A. and Dobbss, L.B. (2011) Citric acid addition improves humic acids action and change proteins profile from plasma membrane of maize roots. Ciencia Rural, Santa Maria. 41(4), 614 - 620.

Saruhan, V., Kusvuran, A. and Babat, S., (2011) The effect of different humic acid fertilization on yield and yield components performances of common millet (Panicum miliaceum L.). Scientific Research and Essays, 6, 663 - 669. 
Sary, G.A., El-Naggar, H.M., Kabesh, M.O., El Kramany, M.F. and Akhoum, G.Sh.H. (2009) Effect of bio-organic fertilization and some weed control treatments on yield and yield components of wheat. World J. Agri. Sci., 5 (1), 55-62.

Smirnof, N. and Wheeler, G.L. (2000) Ascorbic acid in plants. Biosynthesis and function. Current Review in Plant Sciences, 19, 267 - 290.

Xienia, U., Foote, G.C., Van, S., Devreotes, P.N., Alexander, S. and Alexander, H. (2000) Differential developmental expression and cell type specificity of dictystelium catalases and their response to oxidative stress and UV light. Biophys. Acta. 149, $295-310$

Zaky, M.H., El-Zeiny, O.A.H. and Ahmed, M.E. (2006) Effects of humic acid on growth and productivity of bean plants grown under plastic low tunnels and open field. Egypt. J. Appl. Sci., 21, 582 - 596.

(Received: 9/11/2014;

accepted:7/12/2014) 
إنتاجية الحبوب و الزيت نتيجة رش فول الصويا (Glycine max L.)

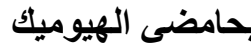
والأسكوربيك مع أو بدون تثعيع البذور

$$
\text { قايمن محمود حلمي - كلية الزر اعة - جامعة الزقازيق - الزقازيق - مصر }
$$

تم إجر اء تجربة حقلية لتقييم التأثير المفيد للرش بأستخدام مضادات الأكسدة متمثلة

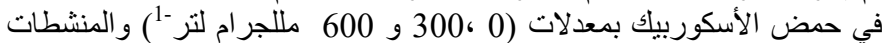

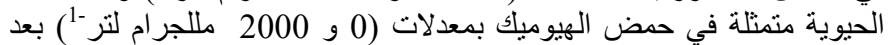

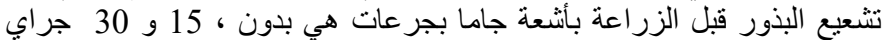

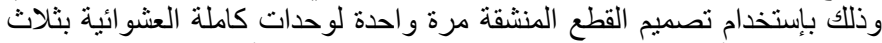

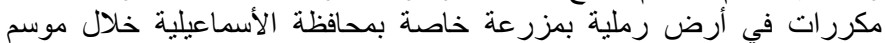

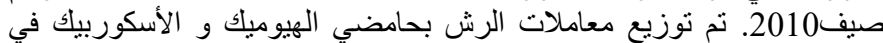

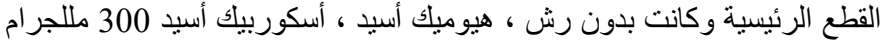

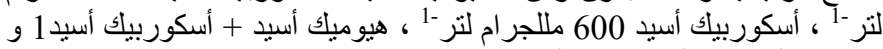

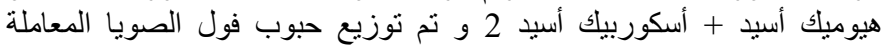

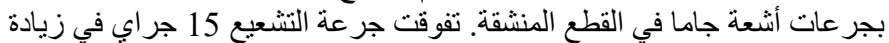

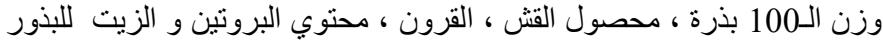

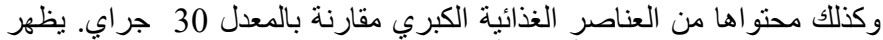

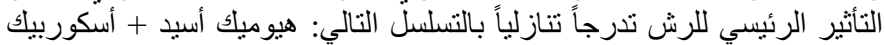

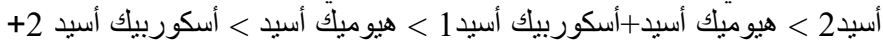

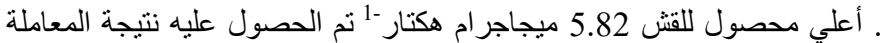

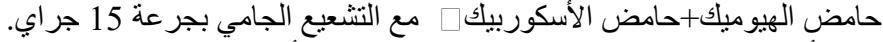

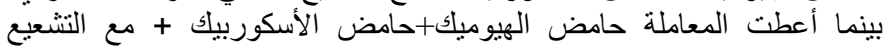

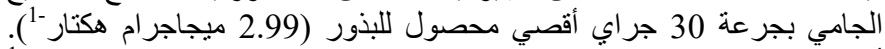

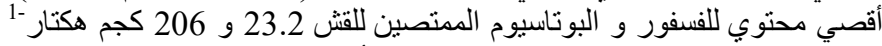

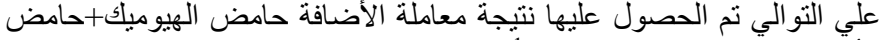

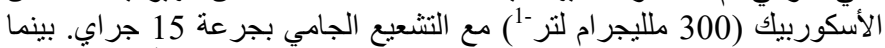

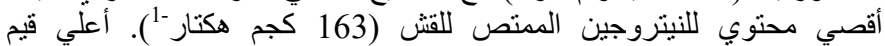

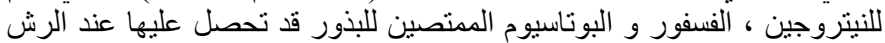

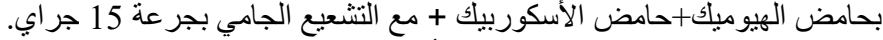

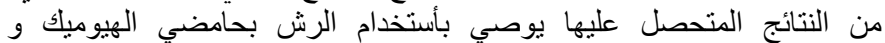

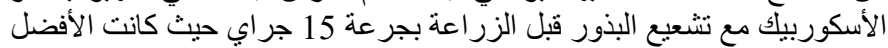

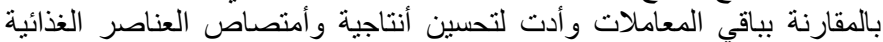
بو اسطة فول الصويا. 